\title{
A projeção especular da imagem do artista e o jogo de enunciação
}

Carolina Tomasi ${ }^{1}$ e Saulo Nogueira Schwartzmann²

Pós-doc (2015), doutora (2014) e mestre (2011) em Letras pela Universidade de São Paulo. Membro do Grupo de Estudos Semióticos da USP (GES-USP). tomasicarol@usp.br

2 Mestre (2014) e doutorando em Letras pela Universidade de São Paulo. Membro do Grupo de Estudos Semióticos da USP (GES-USP). saulosns@gmail.com 


\section{Resumo}

Bastam apenas as categorias de enunciação, enunciva e enunciativa, como estratégias de produção de sentido de pinturas e de fotografias? Este artigo objetiva discutir exatamente essa questão. A ideia de modernidade se impõe não como um saber, nem como ciência, mas como modo de reflexão do próprio fazer artístico. Temos a partir de então a explicitação do enunciador (o artista) no enunciado, um simulacro do criador na criatura. Configura-se como objeto deste trabalho a análise da foto de Helmut Newton Autorretrato com esposa e modelos para explicitar estratégias de enunciação enunciativa e enunciação enunciva quando são postas em jogo. Analisaremos ainda a projeção da imagem dos artistas na produção de seus enunciados, primeiramente na pintura, e em um segundo momento na fotografia.

\section{Palavras-chave}

Artes plásticas, fotografia, semiótica, enunciação.

\section{Abstract}

Does it only take the categories of enunciation, enuncive and enunciative, to produce a sense in paintings and photos? This article aims to discuss exactly this issue. The idea of modernity imposes itself not as knowledge, nor as a science, but as a way of reflection of the artistic practice itself. Thus, we have the explanation of the enunciator (the artist) in the statement as a simulation of the creator in the creature. The subject of this study is the analysis of Helmut Newton's picture Self-portrait with wife and models, in order to explain enunciative and enuncive enunciation strategies when they are at stake. Also, we aim to analyze the projection of imagery of artists in the production of their statements, first in painting, then in photography.

\section{Keywords}

Visual art, photography, semiotics, enunciation. 


\section{Simulacro de distanciamento do artista: a mimese na arte}

Platão, em A República, entendia haver duas realidades: o mundo das ideias e o mundo da aparência. A mimese era então vista como imitação da "aparência das aparências", pois o mundo natural seria uma cópia do mundo das ideias. Ao artista cabia reproduzir uma imitação de uma aparência. Daí seu juízo moral de que o artista apresentava o falso como verdadeiro, ludibriando o público/espectador. O segundo grego a dedicar-se ao conceito de mimese é Aristóteles. Na Poética, a mimese seria uma atividade por meio da qual o artista percebe formas existentes do mundo natural, não simulando aparências.

O desenho renascentista estabelece um efeito de sentido harmônico, de relações espaciais equilibradas. Michelangelo, por sua vez, rompe antes do sopro seiscentista com esse equilíbrio. A maioria dos corpos que pinta, desenha ou esculpe, embora parta de modelos canônicos clássicos, acaba aproximandose dos dados sensíveis à representação de algo que não existe na realidade.

Diferentemente dos artistas clássicos do século XVI, para os quais a arte consistia em imitar modelos greco-latinos, os artistas seiscentistas eram tidos como enigmáticos, engenhosos, agudos; essa engenharia nada mais era do que projeção discursiva. Podemos dizer que da Idade Média ao Renascimento, esse princípio de imitação nos leva à reflexão de que o artista está destinado a imitar a obra de Deus, reproduzindo a natureza tal como ela surge no mundo natural, com significante (expressão visual/sonora) e significado (conteúdo) manifestados à percepção do homem criador. A esse tipo de arte podemos aplicar o conceito de enunciação enunciva. Nesse regime enuncivo, temos um "ele", um "então" e um "lá", certa onisciência. Para melhor entendimento, temos um simulacro de terceira pessoa (distância/afastamento).

A enunciação é o lugar em que se instaura um sujeito, o qual se constitui ponto de referência das relações espaço-temporais. Greimas e Courtés (2008) estabelecem que a competência discursiva é constituída pelo conjunto de procedimentos que se destinam a constituir o discurso (verbal, plástico) como um 
espaço e um tempo pelo qual transitam atores/personagens que se diferenciam ou se identificam com um enunciador, a depender do enunciado. Tal enunciação se forma na relação entre coenunciadores e pode se dar ou não tal relação no próprio enunciado. É uma instância de produção do discurso, que ocorre num tempo postulado como "aqui" e "agora" dos coenunciadores, os quais são marcados pela relação entre um eu e um tu. Essas categorias discursivas são semiotizadas por meio dos dispositivos gramaticais de uma língua.

Ora, se são preconizadas por uma gramática, servem as categorias de enunciação, enunciva e enunciativa, como estratégias de produção de sentido de pinturas e de fotografias? Este artigo objetiva discutir exatamente essa questão.

A incompreensão da imitação enquanto conceito estético vem do fato de que alguns artistas eram arredios à ideia de que o produtor da arte devesse copiar servilmente, tentando atingir a mimese em seu grau mais elevado. Houve, portanto, um empenho da criação artística em explicar-se a si mesma, esgotando todos os recursos da linguagem com o escopo de se confirmar sua própria modernidade (GROULIER, 2004,). Esse empenho se caracterizou por simular a presença do "eu" nos enunciados. Tal procedimento chamaremos, neste artigo, de assinatura pictórica.

\section{Assinatura pictórica: o desejo do criador de mostrar-se na criatura}

A ideia de modernidade se impõe não como um saber, nem como ciência, mas como modo de refletir o próprio fazer artístico. Não uma cena a ser referendada, mas uma cena produzida por um criador pela própria tessitura da linguagem. Para que haja uma possibilidade de atualização de uma experiência estética faz-se necessário um espectador que não se agarre na busca de um efeito de sentido mimético/icástico (certamente não o encontrará nos experimentalistas ou na pós-modernidade) e que aceite a experiência de obscuridade da invenção autoral (cf. também LIMA, 2003, p. 171 ss). Temos, a partir de então, a engenhosidade de explicitação do enunciador (o artista) no enunciado, um simulacro do criador na criatura. É como se, estando dentro do 
objeto produzido, o artista efetuasse a "conjunção eterna" com o objeto criado; um desejo apenas, pois, uma vez ali na fotografia, na tela, na literatura, o artista nada mais é do parte do próprio enunciado: projetado em primeira pessoa (eu), mas visto pelo enunciatário como terceira pessoa (não-pessoa), um outro ator/ personagem qualquer, parte integrante da cena, da foto, da pintura.

Em decorrência dos efeitos produzidos (em primeira pessoa ou em terceira pessoa), nos enunciados pictóricos e poéticos, são erigidos efeitos de subjetividade no regime enunciativo e de objetividade no enuncivo. No primeiro, temos uma aproximação do artista; no segundo, ele parece menos envolvido com o enunciado que "sem sua presença". Seguindo essa discussão, alguns artistas na história da arte se projetaram em suas obras. Na literatura, a presença do "eu", produzindo efeito de subjetividade, é manifestada por pronomes pessoais, possessivos, flexões verbais, advérbios de lugar e de tempo. Nas artes plásticas, no regime enunciativo, essas categorias gramaticais são representadas de outra forma: presença do artista em uma tela (como veremos a seguir), sua assinatura, seu rastro. Da mesma forma, podemos dizer que também na fotografia tal regime enunciativo ocorre por meio da presença, da simulação, do fotógrafo na fotografia (assinatura pictórica).

Configura-se ainda como objeto deste trabalho o exercício de leitura da foto de Helmut Newton Autorretrato com esposa e modelos, para explicitar algumas estratégias de simulação de afastamento e de aproximação do artista quando em jogo num mesmo enunciado. Em seguida, comentaremos a projeção da imagem dos artistas na produção de seus enunciados, primeiramente na pintura, e em um segundo momento na fotografia.

\section{A projeção da imagem do artista nas artes}

A projeção do artista na pintura

Verificando a história das artes, podemos constatar como é comum o artista penetrar em sua própria obra de arte, registrando sua presença quando 
se mostra para o enunciatário ("estive/estou aqui"). Por essa razão, iniciaremos esta seção observando algumas telas que mostram diferentes projeções de enunciadores: artista mais evidenciado e acentuado e artista menos evidenciado e atenuado.

O artista em evidência: a acentuação em Rembrandt, Velázquez e Coubert

Nessa amostra, o artista projeta-se, revelando ser o produtor/criador do objeto artístico. No quadro O artista em seu estúdio, de Rembrandt, o enunciador projeta-se no enunciado como produtor da tela, um performático por excelência:

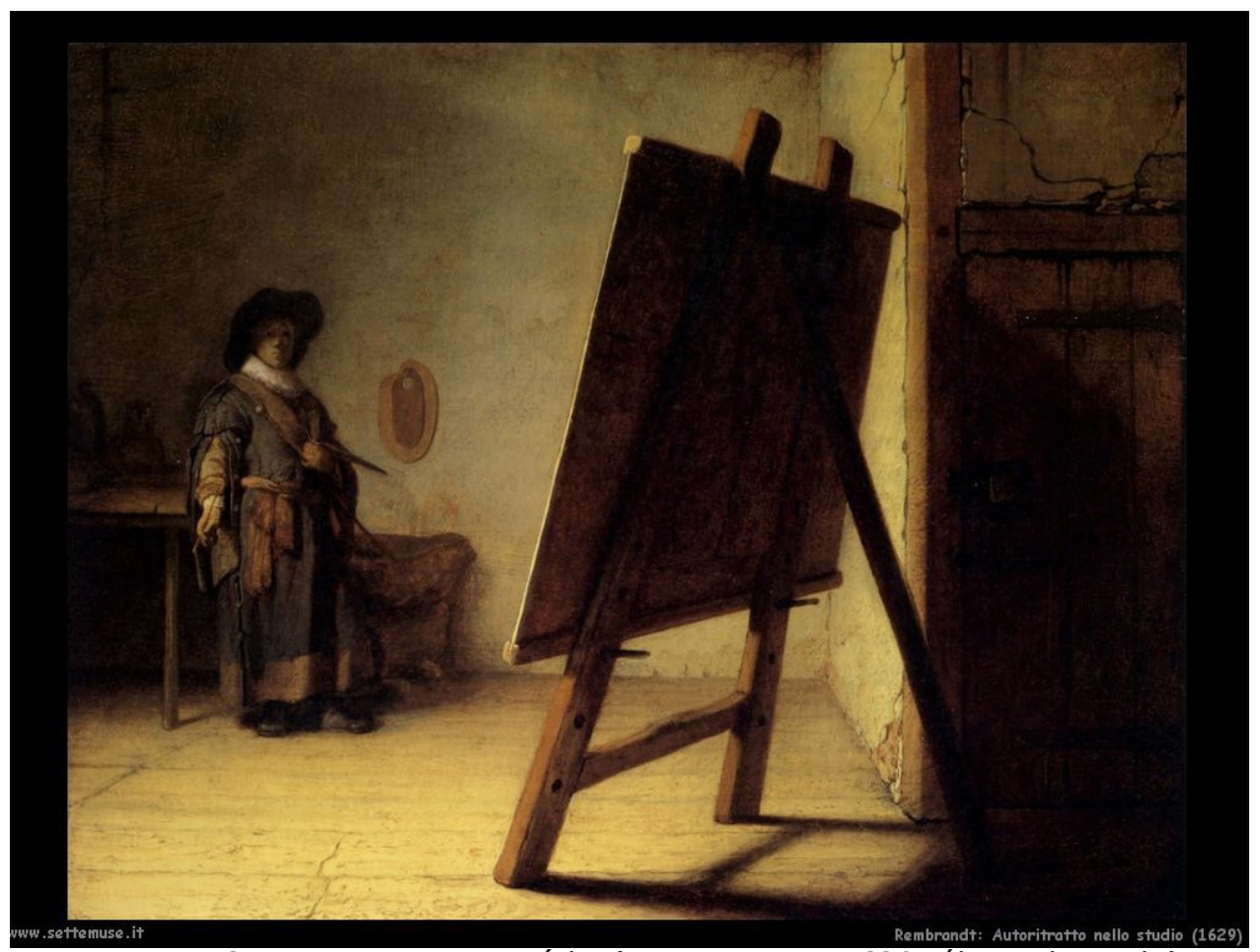

Figura 1:O artista em seu estúdio (REMBRANDT, 1629, óleo sobre tela)

No quadro As meninas, de Velázquez, é o próprio ato de produzir que salta da tela. Pode-se observar tal "fazer" artístico do pintor no texto: 


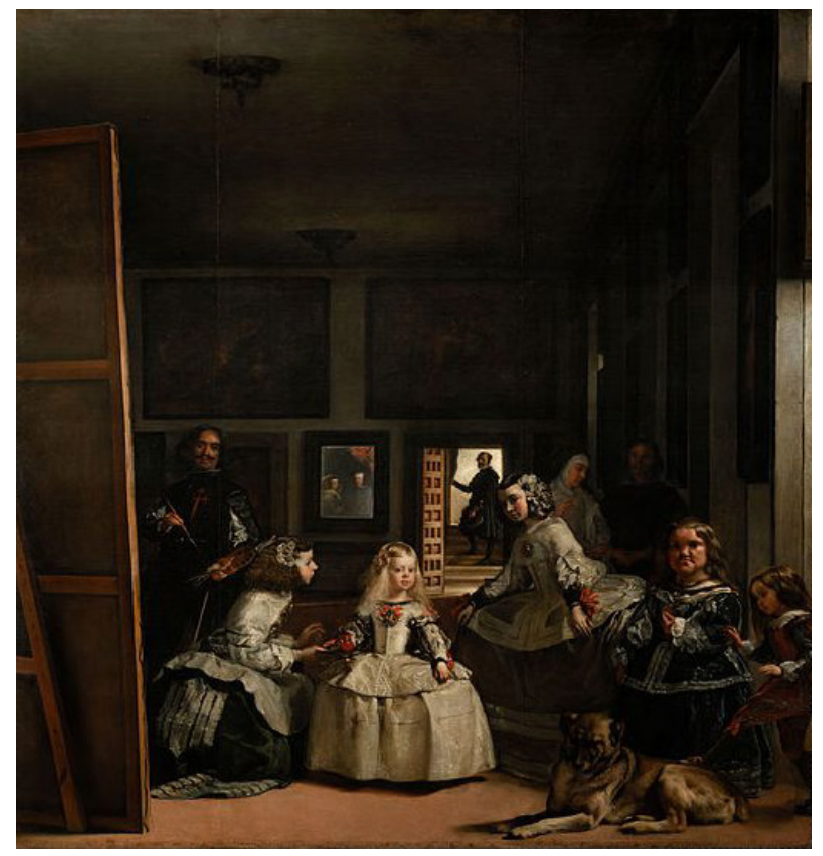

Figura 2: As Meninas (VELÁZQUEZ, 1656, óleo sobre tela)

Enquanto registro do fotografar, há metalinguagem, havendo reflexão sobre o próprio fazer artístico. Acentua-se a competência do pintor quando se revela "a pintura do pintar", ou seja, temos um tipo de assinatura pictórica evidenciada. Observamos no centro do quadro um pintor sentado pintando um quadro. Vejamos outro exemplo:

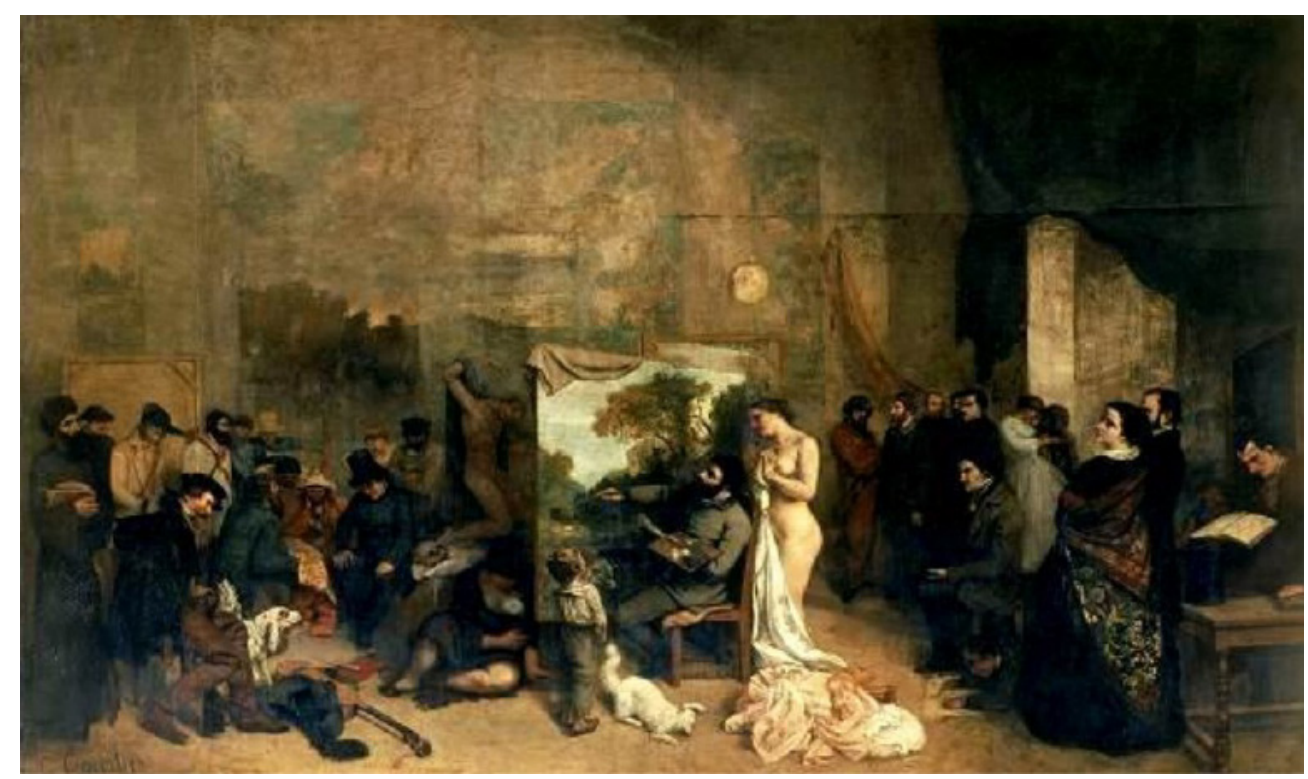

Figura 3: O ateliê do pintor (COUBERT, 1855, óleo sobre tela) 
Nas telas citadas, o enunciador do discurso é projetado como uma figura da cena enunciada. Em lugar de destaque, o pintor aparece no ponto central do quadro, no próprio ato de pintar.

Artista menos evidenciado: a atenuação em Van Eyck

Em Van Eyck, o enunciatário toma contato com o enunciador de forma indireta por meio da projeção do artista em um pequeno espelho pendurado na parede. O pintor, Van Eyck, aparece no fundo, como testemunha da cena em $O$ casal Arnolfini.

Na tela, o jovem casal troca juras matrimoniais no interior de seu quarto. Parecem estar a sós; todavia, o espelho atrás deles revela ao espectador a presença do pintor, uma vez que se encontra escrito em cima do espelho "Johannes de eyck fuit hic, 1434" (Jan van Eyck esteve aqui, 1434). O papel do enunciador, na figura do pintor, é, portanto, o de testemunha: o "ator-pintor" sincretiza o papel de "enunciador" e de "destinador julgador", quando aprova positivamente o casamento (GREIMAS, 2008, p. 426). A tela (figura 4) é a narrativa de um casamento pictórico, com a presença do pintor como testemunha, retratando a prática semiótica da assinatura em certidões de casamento (JANSON; JANSON, 1996):

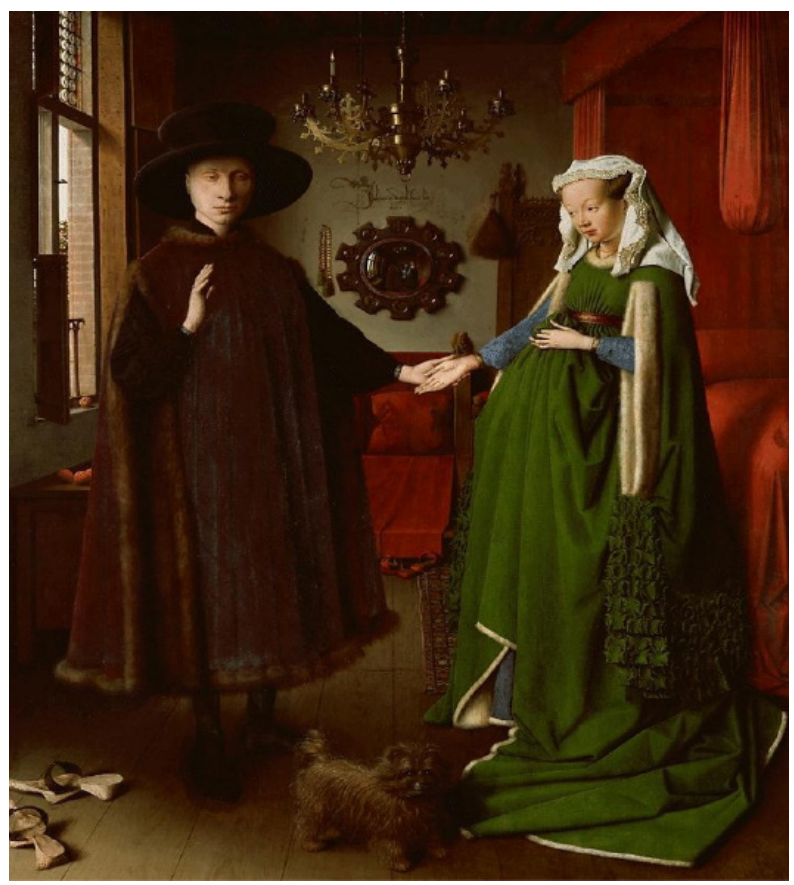

Figura 4: O casal Arnolfini (Van Eyck, 1434, óleo sobre tela) 
Guardadas as proporções, a presença do pintor assemelha-se aos enunciadores machadianos que a todo instante penetram a cena enunciativa, travando um diálogo com o leitor. Trata-se de uma aproximação estratégica para granjear-lhe a simpatia. Pessoa, tempo e espaço estão subordinados à enunciação e estão articulados enunciativamente (projeção de primeira pessoa) e enuncivamente (projeção de terceira pessoa).

Até o momento, constatamos dois tipos de artistas em cena: (a) um tipo de artista/pintor mais evidenciado, que se projeta como produtor do objeto artístico (quadro 1, 2 e 3) e (b) outro artista/pintor menos evidenciado (quadro 4). Apropriando-se dos aportes metodológicos da semiótica tensiva, depreendemos dois tipos de criador: (1) um que se evidencia mais: aqui, a presença do artista como produtor é acentuada e tonificada; (2) um que se evidencia menos: aqui, a presença do artista como produtor é menos acentuada e mais atenuada. A arte, nesse caso, não se faz com exclusividade de um ou de outro eixo, mas da mistura de ambos os tipos.

Vejamos a seguir como o artista mais evidenciado aparece na fotografia sob leitura e como podemos compreender o jogo aproximações e distanciamentos na foto de Helmut Newton.

\section{A projeção do artista na fotografia Autorretrato com esposa e modelos}

A foto de Helmut Newton, objeto de exercício de leitura deste artigo, é intitulada Autorretrato com esposa e modelos. Filho de uma americana com um judeu-alemão, Helmut nasceu em Berlim, em 1920. Interessou-se por fotografia quando jovem, tendo trabalhado como aprendiz da fotógrafa alemã Yva, especialista em nus, retratos e moda. Em 1946, inaugurou seu primeiro estúdio fotográfico e deu início ao seu relacionamento com a moda. Casouse um ano depois, quando fotografou a jovem modelo June Brunell, que viria a se tornar June Newton. Em sua autobiografia, o fotógrafo alerta a June: "meu trabalho virá sempre em primeiro lugar". Até a morte de Newton, em um acidente de carro na Califórnia, em 2004, June foi, além de companheira, 
assessora do marido, acompanhando-o em seus ensaios (figura 5), sessões de fotos e viagens, sempre registrando os bastidores daquele universo.

Nas imagens de Newton, as mulheres encontram-se majoritariamente nuas ou em atos erotizados. Os espaços de seus enunciados são, muitas vezes, públicos, como quartos de hotel, configurando narrativas entre sujeitos desconhecidos. Em um mundo repleto de marcas e supervalorização da moda, fica evidenciada a preferência do fotógrafo por corpos desvestidos, uma escolha pela não marca e pela tensão entre identidade marcada (o fotógrafo assim como sua mulher estão marcados pela roupa) e alteridade não marcada (duas não pessoas desvestidas, sem marca, uma em pé e outra sentada):

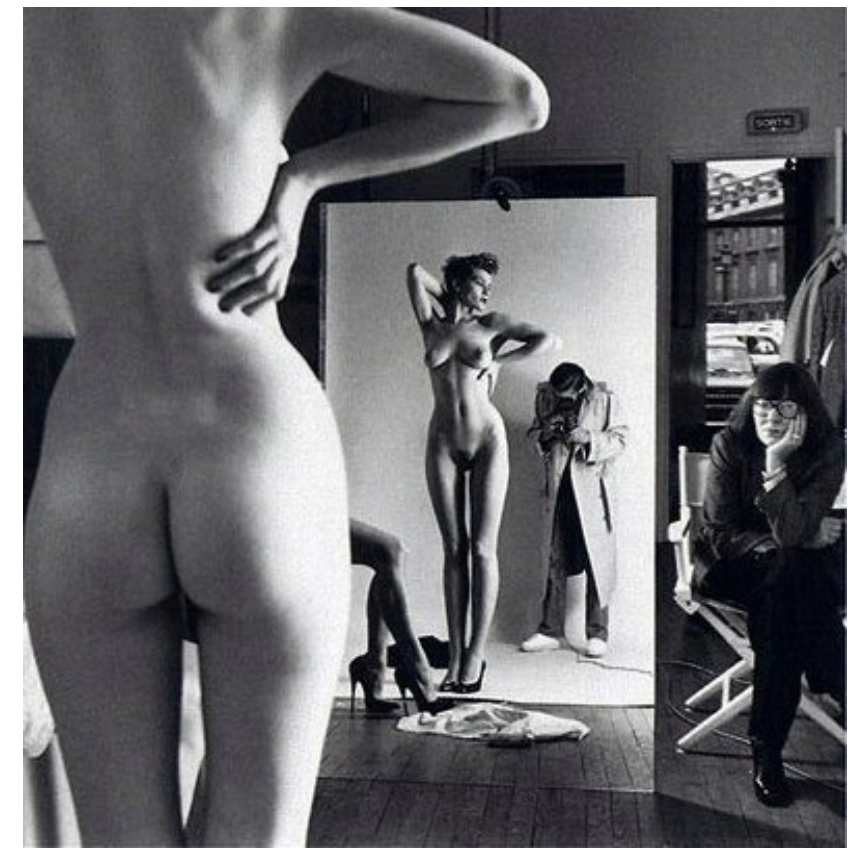

Figura 5: Autorretrato com esposa e modelos (NEWTON, 1980)

Na foto, temos o fotógrafo refletido no espelho, as modelos nuas sendo fotografadas (uma em pé e outra sentada) e a mulher do fotógrafo que observa o trabalho do marido (sabemos que é sua mulher devido à declaração de Helmut Newton em uma entrevista). O artista, no objeto-alvo deste artigo, projeta sua própria imagem, intitulando-a de Autorretrato. Selfie-portrait é uma prática corriqueira no pós-modernidade com sua característica de questionar a representação pela arte, incluindo o artista dentro do objeto produzido. A história 
da arte conta com muitas produções de autorretrato, mas talvez nunca como nos tempos modernos e contemporâneos. Tendo os artistas experimentado a focalização do mundo natural ("não eu" no renascimento, da expressão "eu" no romantismo), chegam à modernidade trazendo em suas produções as inquietações da metalinguagem, quando desejam revelar aos seus pares e aos seus telespectadores que são "criadores" de competência e de mestria técnica.

Há na foto de Helmut Newton, em evidência, o fotógrafo (simulacro do enunciador-artista) que fotografa e é visto fotografando uma modelo e o espectador que assiste à cena toda ao mesmo tempo em que é produzida (claro, o que vemos é a cópia do momento de reprodução). O "voyeurismo", então apresentado no enunciado da fotografia, dá-se por meio das figuras da esposa do fotógrafo que tudo vê e da modelo sentada que é vista pelo fotógrafo, pela sua mulher e pelo enunciatário e que vê também sua colega sendo fotografada.

Nesse sentido, a pintura ou a foto, cuja imagem do artista se deixa ver pelo espectador, coloca em foco o artista. Alguns pintores/fotógrafos se retratam em situações de trabalho: o enunciado da foto mostra a performance do fotógrafo, um tipo de revelação do ato de enunciação, ou seja, um desejo de "congelar" o momento célebre de produção do objeto. Nesse sentido, o semblante do artista não se apresenta em momento de transe e de relaxamento, mas em situação de criação. Ora, o pintor e o fotógrafo apresentam-se compondo, criando, como se revelassem os bastidores da tela, da fotografia, como é o caso do makingof no cinema (muito comum, atualmente, a curiosidade do espectador pelos bastidores do processo criativo). O fotógrafo faz-se ver ao olhos do espectador como produtor do objeto em cena. É um tipo de vaidade do ofício artístico, que, em vez de se apresentar como inspiração ou momento de insight, institui-se como "trabalho", "labuta".

De certa forma, o artista é configurado como um sujeito competente em sua mestria, que é capaz de produzir um objeto artístico e entregá-lo ao espectador, ao "leitor". Na foto de Helmut Newton, ilusoriamente, o corpo feminino aparece em primeiro plano, mas em verdade o primeiro plano é ocupado pelo 
artista que aparece refletido no espelho (o segundo plano é só o reflexo dele, portanto). Nesse caso, a arte fotográfica, e por extensão, a plástica, são lugares de manifestação do eu que se diz "criador", que se diz "mestre" em seu ofício, seja o de pintor, seja o de fotógrafo, evidenciando-se como foco da cena.

\section{O Reflexo do espelho: jogo de pontos de vista na fotografia}

Temos, na fotografia de Helmut Newton, não só um tipo de artista evidenciado em primeira pessoa, próximo do espectador, como também algumas projeções mais distantes (em terceira pessoa) envolvidas no enunciado da foto. Podemos dividir nosso exercício de leitura em três partes:

Primeira parte: o ato de fotografar

$\mathrm{O}$ ato de enunciar a própria obra faz das pessoas seres criadores, o que coloca o homem numa condição divina. O discurso é representacional e não referencial, assim como todas as obras de arte. A fotografia também é uma representação do mundo natural, porque nela há a subjetividade do fotógrafo. Não é, então, banal pensarmos na instauração e na simulação do criador que se coloca dentro da obra. Nesse sentido, enunciar-se como sujeito criador é um procedimento eficaz em que a instância da enunciação "sai de si" e se projeta "além de si". Isso tudo só é possível discursivamente, claro. Desse modo, por meio da categoria de pessoa, primordial para a configuração discursiva, o "eu" se coloca num tempo e num espaço da criação, simulando o momento em que criou, como vimos na foto de Helmut Newton. O ato de projetar o eu, aqui e agora é apenas um recurso do discurso, uma invenção da linguagem, que é capaz de criar mundos. Um enunciado não se reduz apenas à enunciação linguística, compreendendo também os artifícios visuais (recurso das lentes, reflexo produzido pelo espelho), aparatos fundamentais da linguagem plástica.

Da mesma forma, o próprio ato de fotografar, em uma primeira instância na fotografia sob análise, é uma projeção do eu que se enuncia como criador; nesse sentido, todo artista-enunciador instaura-se em um discurso na direção de um 
enunciatário-espectador; em outros termos, o movimento é da identidade para alteridade. A enunciação em primeira pessoa, que evidencia o artista, configura, então, nessa primeira etapa da análise, uma relação "eu-tu" instaurada entre o fotógrafo, figurativizado com precisão no centro do enunciado, e as modelos na periferia (ambos personagens/atores do enunciado).

A esposa do fotógrafo (mulher de óculos), retirada logo abaixo do objeto nesta etapa da leitura, numa primeira "visada", seria no enunciado uma "não pessoa" (não seria nem "eu" nem "tu"). Ela constitui-se num voyeur, diferentemente do fotógrafo, que participa da cena ativamente. A título de exemplificação, recortamos a foto para mostrar essa enunciação em primeira pessoa (eu-tu):

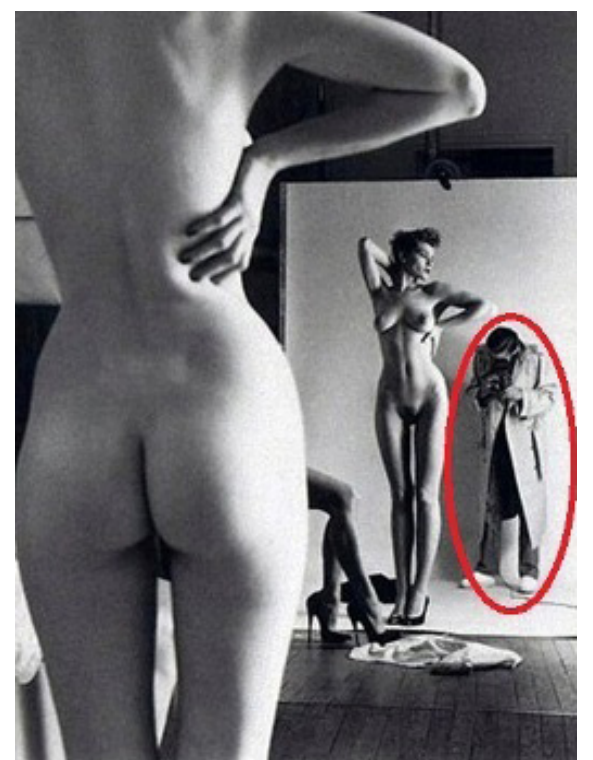

Primeira parte: Enunciação enunciativa (eu-tu)

A instauração do fotógrafo na fotografia, circulado no texto, configura sua presença no discurso e, como consequência, a do enunciatário-espectador que, nessa primeira instância, aparece figurativizado nas modelos. Podemos afirmar que o artista precisa da solidariedade do enunciatário. Não há arte sem seus pares: existe uma espera pelo objeto. O "degustador" da obra do artista já está presente na própria obra, transfigurado em constituinte do quadro, ou da foto, no caso. O enunciatário/espectador, colocado também dentro da obra, é elemento constituidor, portanto. 
Segunda parte: a foto como objeto de arte

Uma segunda instância pode ser analisada: a de uma enunciação em terceira pessoa, mais afastada, em que se nota a proposta de um enunciado ou de um objeto que dissimula se afastar da subjetividade da primeira parte. Nela, notamos uma fotografia das modelos e da esposa do fotógrafo, bem como a do reflexo do próprio fotógrafo, cujas figuras são as performances do voyeurismo na fotografia e a exposição erótica das modelos. O espelho intensifica ainda mais o voyeurismo, pois mostra para o espectador o olhar dos atores "voyeurs" [a mulher do fotógrafo e a modelo que está sentada]. Por consequência, o espectador também assume a posição de um voyeur, de nível secundário, de um objeto reproduzido, porque ele vê a imagem refletida no espelho. Assim, trata-se da figurativização de um adjuvante-facilitador da visão do espectador, na medida em que lhe possibilita visão semelhante à dos sujeitos projetados no enunciado da fotografia, os voyeurs de nível primário. Uma obviedade, todavia, deve ser mencionada: a de que o enunciatário-espectador da terceira instância (ver terceira parte) é o voyeur absoluto, uma vez que é espectador da totalidade do objeto. Colocando a segunda instância lado a lado, temos:

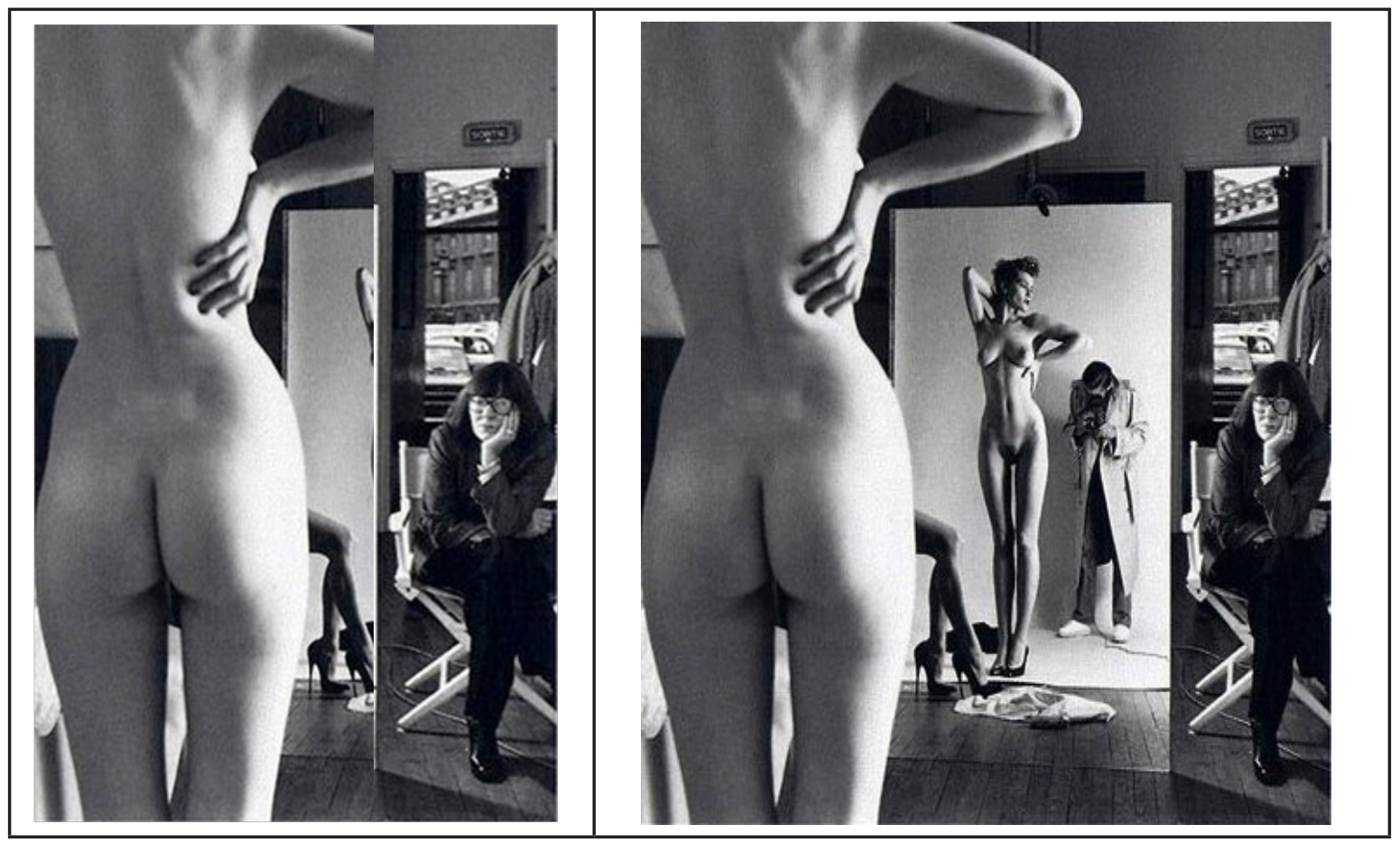

1 a instância: Eu (pressuposto)-Tu / Ele (voyeur primário)

$2^{a}$ instância da não pessoa: Efeito de objetividade: o eu pode ser visto como "não eu"; instauração das pessoas fotografadas (voyeur secundário). 
Essa segunda instância de enunciação instaura as pessoas fotografadas como terceira pessoa (ele): um efeito de sentido objetivo. Embora a figura do enunciador-artista continue ali, também ele foi fotografado, tornando-se objeto de admiração. Há nessa segunda instância certa complexidade, pois se acumulam a figura do criador, que é compositor da foto, e a figura do ator/ personagem, alvo do espectador. Ainda, ao mesmo tempo em que se subjetiva como artista, objetiva-se como alvo de mirada. Nesse sentido, a instância do "eu" nesse segundo tipo de enunciação pode ser vista também como "não-eu", uma vez que objetivamente o próprio fotógrafo também faz parte do objeto "fotografia".

\section{Terceira parte: a foto como metalinguagem}

Ao recorrermos à primeira parte da leitura, ocorre-nos outro tipo de movimento, só que agora com base na relação entre o enunciador fotógrafo e o enunciatário "degustador" da fotografia, outro tipo de relação eu-tu. A presença do enunciador fotógrafo no reflexo do espelho já é uma razão semiótica para que este exercício de leitura apontasse três tipos de enunciação. A terceira instância seria a da metalinguagem na fotografia. Observemos, nesta terceira parte, o estatuto semiótico do enunciatário/espectador.

A primeira enunciação entre o "enunciador fotógrafo" e os "fotografados" só tem existência semiótica devido à terceira enunciação, a que destacamos entre o enunciador fotógrafo e o enunciatário "degustador" da fotografia, o chamado "leitor". É nesta última instância entre artista e público, ambos sujeitos da enunciação, que se dá o objeto "fotografia". Na análise dessa instância, consta do enunciado (a foto como texto) a perna da modelo, a modelo de costas e da esposa do fotógrafo (fora do reflexo do espelho); no reflexo do espelho, temos a modelo fotografada e o enunciador fotógrafo e a pressuposição, portanto, de um enunciatário "leitor". Note que contidos no reflexo do espelho estão apenas o fotógrafo e a modelo refletida por inteiro e as pernas da outra modelo. E o que ficou de fora do reflexo do espelho? June (de óculos), um corpo sem cabeça e um 
corpo sem perna; todos esses elementos devem ser preenchidos/catalisados pelo enunciatário/degustador da foto. Convoco aqui o estatuto dos objetos abertos (cf. TOMASI, 2014), com ponto de fuga inclinado, diferentemente do ponto de fuga clássico (convergente para o centro do quadro), ocorrência comum desde o período seiscentista com Caravaggio:

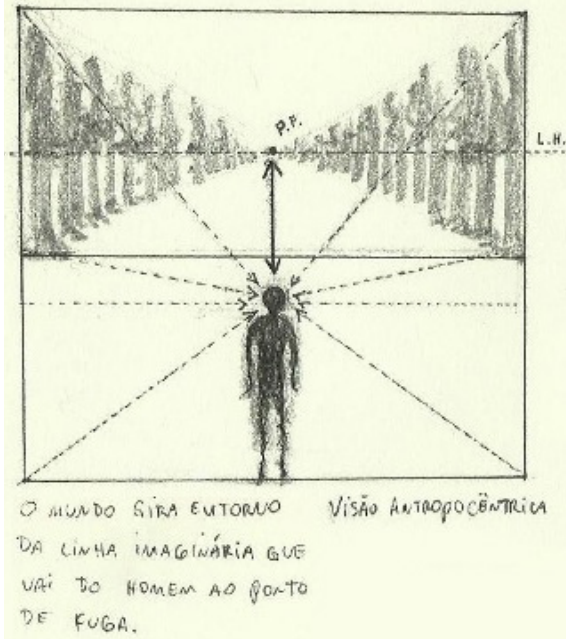

Clássico

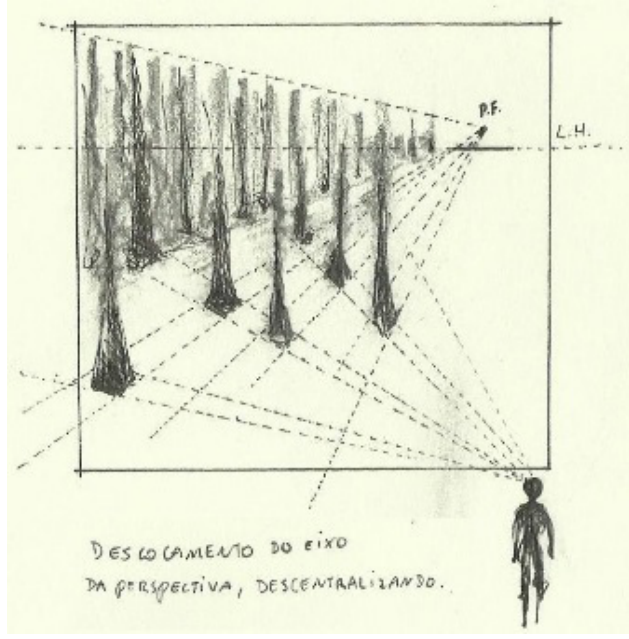

Fonte: retirado da tese de Tomasi (2014).

Ora, se o objeto da enunciação é o enunciado, no caso, a fotografia, temos, então, a razão da existência de qualquer objeto semiótico, ou seja, os objetos semióticos se mantêm por meio dos sujeitos da enunciação (enunciador/ produtor e enunciatário/espectador) que almejam a conjunção com o objeto "enunciado"; isso se estende a todos os textos (poesia, romance, filme). Esse ato de enunciação inicial é o que engendra a significação. Nesse caso, a terceira 
parte desse emaranhado de enunciações só se dá como metalinguagem, porque tem como pressuposto o ato de fotografar, o ato de pintar, o ato de escrever e assim por diante, e o contrário também vale, pois a primeira enunciação só pode ser recuperada a partir da última. É como se fossem interdependentes, um jogo de enunciações, portanto. Esse procedimento gera a instauração da função metalinguística, ou seja, no enunciado da fotografia analisada, tenta-se recuperar o momento de produção da fotografia, um simulacro do "congelamento" do ato da enunciação, em que a linguagem da fotografia recai sobre si mesma. Trata-se da exibição do fazer do fotógrafo. Contrapõe-se à mimese que tende a mitificar a realidade como "real". Ora, tudo é discurso. No caso da foto de Helmut Newton, temos um excesso de "transparência", de "honestidade" do fotógrafo: é apenas um parecer de "verdade" do momento da criação. Ele mostra ao enunciatário todas as artimanhas da consecução do objeto. É a revelação do criador, de sua competência. Mesmo assim Helmut Newton, engenhosamente, não consegue nos mostrar tudo, pois há um corpo a ser preenchido ainda, o corpo das penas refletidas no espelho. Como será essa modelo?

Fica uma abertura para a atividade do espectador. Como vimos, a obra de arte sob esse ponto de vista pode ser entendida como fruto de trabalho e não de inspiração; daí a metalinguagem se fazer presente nos objetos desde o seiscentos, como vimos em Velazquez.

\section{Três fotografias em uma só}

Para efeito do exercício de leitura, temos três possibilidades de enunciação em jogo:

\begin{tabular}{|c|c|c|}
\hline $1^{\mathrm{a}}$ enunciação $(A)$ & $2^{\mathrm{a}}$ enunciação $(B)$ & $3^{a}$ enunciação $(C)$ \\
\hline $\begin{array}{l}\text { Ator-enunciador fotógrafo } \\
\text { (eu) + Atores Modelos (tu) } \\
\text { = a enunciação em primeira } \\
\text { pessoa; simulacro do efeito } \\
\text { de subjetividade. O fotógrafo } \\
\text { é o criador. }\end{array}$ & $\begin{array}{l}\text { Pressuposição do enunciador } \\
=\text { simula-se o efeito de ob- } \\
\text { jetividade ("eu-tu" agora são } \\
\text { não pessoas, ambos fazendo } \\
\text { parte da foto). O fotógrafo é } \\
\text { também parte da foto. }\end{array}$ & $\begin{array}{l}\text { Enunciador fotógrafo na instân- } \\
\text { cia mais profunda do engendra- } \\
\text { mento do sentido e o enuncia- } \\
\text { tário "degustador" da fotografia } \\
\text { = metalinguagem. A fotografia } \\
\text { volta-se para o fazer do fotó- } \\
\text { grafo. }\end{array}$ \\
\hline
\end{tabular}




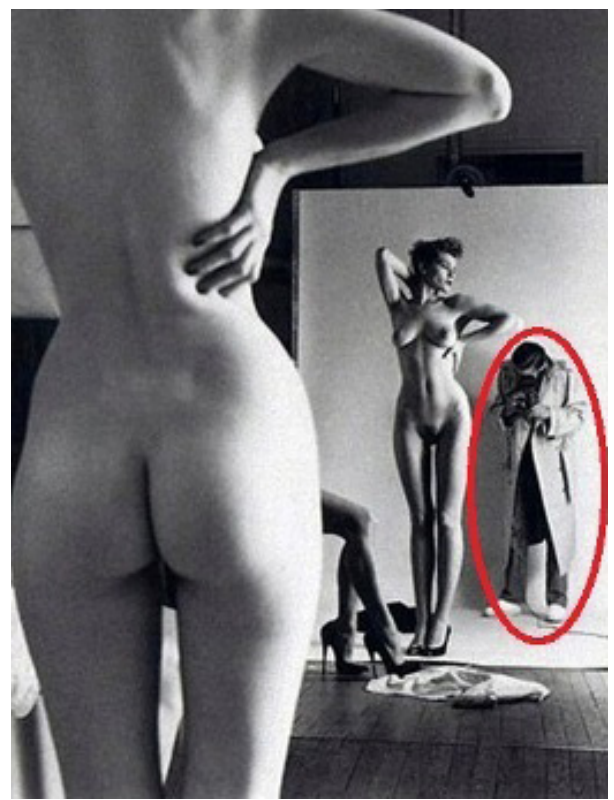

$A$

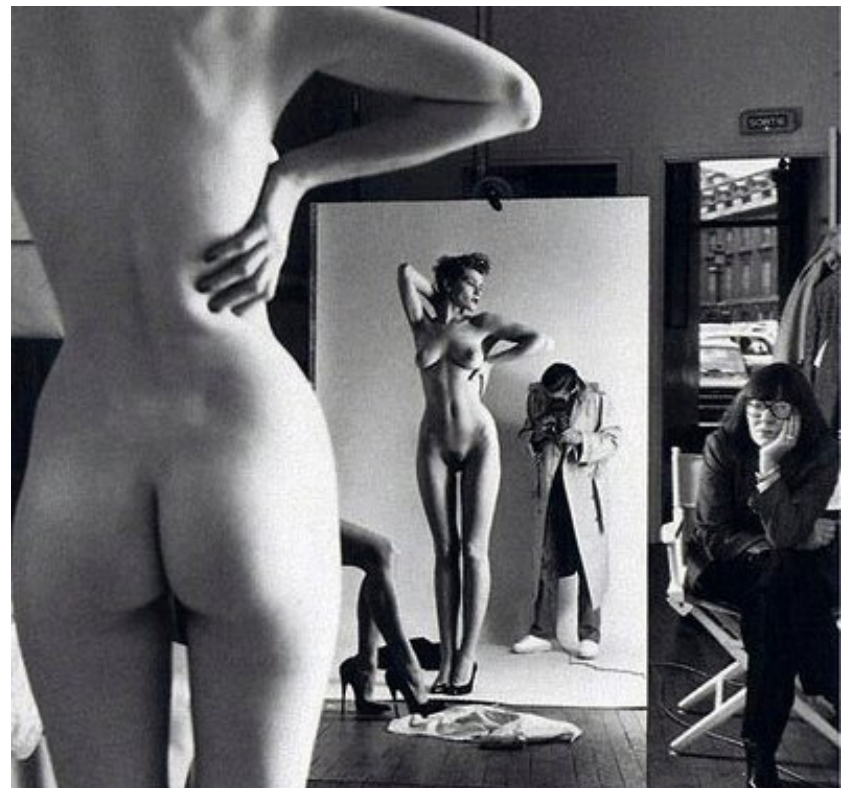

$B$ e $C$

Tomemos nossa leitura pelo movimento de $\mathrm{C}$ para $\mathrm{A}$ :

$3^{a}$ instância (C): Se em todo enunciado podemos pressupor uma enunciação, temos um sujeito da enunciação (enunciador e enunciatário) que almeja um objeto, o enunciado-texto da fotografia. Eis a metalinguagem.

$2^{a}$ instância (B): Efeito de sentido de objetividade: eu (pode ser visto como não eu) - tu (podendo ser visto como não pessoa): todos fazem parte do objeto; mesmo o enunciador refletido no espelho já é parte do enunciado. Logo, no nível discursivo, podemos depreendê-lo como um ator (personagem) qualquer, bem como o tu projetado da primeira instância.

$1^{a}$ instância (A): Enunciação enunciativa (eu-tu): a presença do enunciador (fotógrafo criador) no texto configura sua presença no discurso e, como consequência, a do enunciatário (espectador) que, nessa primeira instância, aparece figurativizado nas modelos.

Esquematicamente:

$1^{\text {a }}$ instância: $1^{\text {a }}$ pessoa 
2a instância: $3^{a}$ pessoa

$\downarrow$

$3^{a}$ instância: simulação do enunciador no momento da produção do enunciado; o desejo de congelar o ato da enunciação

\section{Considerações finais}

Nossa análise pretendeu dissecar as etapas das enunciações em jogo, colocando em questão as categorias de enunciação enunciva ( $3^{a}$ pessoa) e enunciativa ( $1^{\text {a }}$ pessoa) como estratégia de produção de sentido de pinturas e de fotografias. Claro que só é possível fazer tal separação para efeitos de estudo. Como dissemos no início deste artigo, a pintura ou a foto, cuja imagem do artista se deixa ver pelo espectador, coloca em foco o momento da enunciação/criação, que acaba ficando evidenciado. Ademais, a foto de Helmut Newton revela a produção do artista no momento célebre de seu fazer criativo. De certa forma, o artista e seu público são sujeitos semioticamente competentes para manter o objeto artístico no jogo do sentido. Da mesma forma, esse procedimento ocorre na pintura, como vimos em Velazquez, Van Eyck e Coubert.

Em tese, não se pode recuperar o exato instante da criação, pois tudo é discurso e projeção, seja passada seja futura. Trata-se, portanto, de um efeito apenas discursivo, contando com todos os aparatos da lente da máquina fotográfica e do espelho. Qualquer "ato" de enunciação não pode ser resgatado no tempo em que foi produzido. Tempo e espaço são fingidos: colocar o fotógrafo como personagem do enunciado da fotografia, como vimos, é uma dissimulação de "congelamento do artista" que se fotografa no mesmo instante em que labuta. 


\section{Referências}

COUBERT, G. O ateliê do pintor, 1855. Disponível em: <http://galeriadefotos.universia. com.br/uploads/2012_06_01_23_39_010.jpg >. Acesso em: 26 nov. 2015.

GREIMAS, A. J.; COURTÉS, J. Dicionário de semiótica. São Paulo: Contexto, 2008. 543 p.

GROULIER, J. F. Da imitação à expressão. In: LICHTENSTEIN, J. A pintura: da imitação à expressão. São Paulo. Editora 34, 2004, v. 5. p. 9-16.

JANSON, A. F.; JANSON, H. W. Iniciação à história da arte. 2. ed. São Paulo: Martins Fontes, 1996. 475 p.

HELMUT NEWTON. Autorretrato com esposa e modelos, 1980. Disponível em: <http:// blogs.diariodonordeste.com.br/desenroladas/wp-content/uploads/2013/08/fotografiade-moda-helmut-newton-2.jpg >. Acesso em: 26 nov. 2015.

LIMA, Luiz Costa. Mímesis e modernidade: formas das sombras. 2. ed. São Paulo: Paz e Terra, 2003. 295 p.

PIETROFORTE, A. V. Análise do texto visual: a construção da imagem. São Paulo: Contexto, 2007. 104 p.

REMBRANDT. O artista em seu estúdio, 1629. Disponível em: <http://www. settemuse.it/pittori_scultori_europei/rembrandt/rembrandt_129_autoritratto_ nello_studio_1629x.jpg>. Acesso em: 26 nov. 2015.

VAN EYCK. O casal Arnolfini, 1434. Disponível em: <http://4.bp.blogspot. com/-N1RIJmmOo4U/VTQeLLyZEII/AAAAAAAAAfE/J6oi5FM7-w/s1600/arnolfini. jpeg>. Acesso em: 26 nov. 2015. 
VELÁZQUEZ, D. As meninas, 1656. Disponível em: <http://mystudios.com/art/ bar/velazquez/velazquez-las-meninas.jpg >. Acesso em: 26 nov. 2015.

TOMASI, Carolina. Semiótica da agudeza: da negação da euforia barroca ao objeto poético fluido do final do século XX. 2014. 518 p. Tese (Doutorado em Semiótica e Linguística Geral)-Faculdade de Filosofia, Letras e Ciências Humanas, Universidade de São Paulo, São Paulo, 2014.

submetido em: 05 fev. 2015 | aprovado em: 08 jun. 2015 